\title{
Innovative Railway Transport Ecosystem: Practices of Leading Companies
}

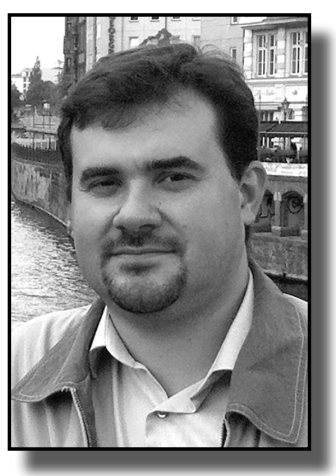

Maxim M. ZHELEZNOV

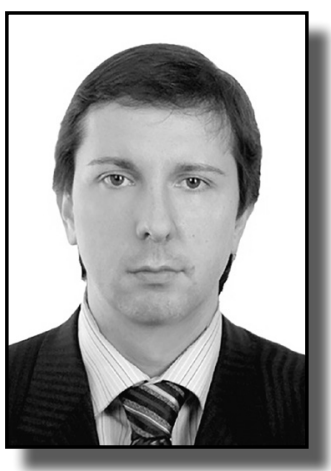

Oleg I. KARASYOV

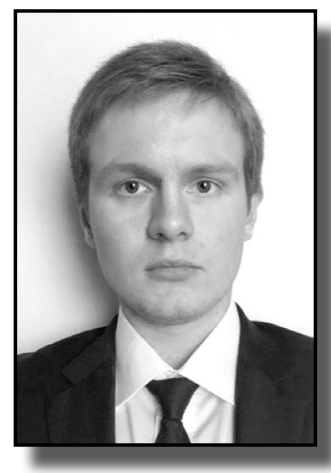

Alexey V. BELOSHITSKY

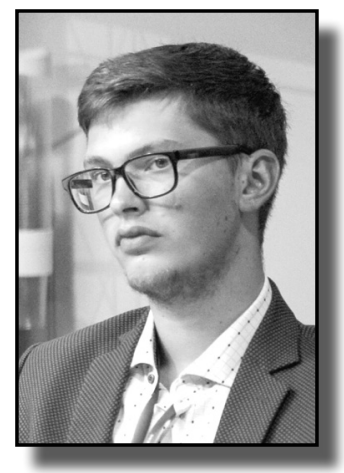

Egor A. SHITOV

Zheleznov, Maxim M., Moscow State (National Research) University of Civil Engineering, Moscow, Russia.

Karasyov, Oleg I., Lomonosov Moscow State University, Moscow, Russia.

Beloshitsky, Alexey V., Lomonosov Moscow State University, Moscow, Russia.

Shitov, Egor A., Lomonosov Moscow State University, Moscow, Russia*.

\section{ABSTRACT}

The railway industry is one of the key areas of transport activity for many countries, in particular for the Russian Federation. The innovative development of this industry and of its corporate actors is an important aspect of development of economy and infrastructure of the respective countries.

An innovative ecosystem creates an enabling environment necessary for such development.

The objective of this article is to analyze the components of the innovation ecosystem: the ways of organizing innovative activities, suggesting their classification into internal and external types of organizations. The study is based on a comparative analysis of the practices of the most competitive world railway companies.

The results show that railway companies using tools of both external and internal types are characterized by a high level of competitiveness and technological development. If the external type of organization of innovative activity has a positive effect on reducing costs, and also promotes active interaction with core external companies, then a one-sided orientation to it leads to an increase in dependence on third-party organizations.

Carrying out research and development within the framework of own innovative laboratories and $R \& D$ centers allows railway companies to significantly reduce this dependence, but leads to a high level of costs, increases the risk of obtaining results that do not correspond to the best world standards. The optimal and effective way to organize the innovation activity of a railway company is to implement a mixed type organization, which includes elements of independent research and development and active interaction with external organizations, companies and experts. This choice is confirmed by the activities of most of the analyzed companies. At the same time, it is important to choose the directions of technological development, within which it is possible and expedient to conduct independent research and development at the present time, as well as those requiring further development of competencies for independent research activities as well as for participating in innovative consortia.

Keywords: innovation ecosystem, railway industry, research and development, hackathon event, startup, business incubator, business accelerator, venture capital fund, innovation stimulation.

\section{*Information about the authors:}

Zheleznov, Maxim M. - D.Sc. (Eng), associate professor, professor of the department of information systems, technologies and automation in civil engineering of Moscow State (National Research) University of Civil Engineering, Moscow, Russia, M.Zheleznov@mail.ru.

Karasyov, Oleg I. - Ph.D. (Economics), director of the Center of scientific-technological forecasting of the economic faculty of Lomonosov Moscow State University, Moscow, Russia, oikarasev@econ.msu.ru.

Beloshitsky, Alexey V. - Master in Economics, deputy director of the Center of storage and analysis of big data of Lomonosov Moscow State University, Moscow, Russia, alex.v.beloshitskiy@gmail.com.

Shitov, Egor A. - Master in Management, leading specialist of the Center of storage and analysis of big data of Lomonosov Moscow State University, Moscow, Russia, egor.shitov29@gmail.com.

Article received 01.07.2019, accepted 29.08.2019.

For the original Russian text of the article please see p. 244. 
Background. The current stage of development of the world economy is determined by the formation of the paradigm of the sixth wave of innovation and the rooting of the principles of the industry 4.0 [1]. The main direction of development in these conditions is the massive digitalization of all sectors of the economy and social sphere.

Industries with the necessary scale of production can become the drivers of breakthrough scientific, technological and socio-economic development, in particular of introduction of advanced technologies [2].

One of the industries with the necessary scientific and technical backlog, scale and potential synergistic effect on related industries is the railway industry [3].

Objective. In this regard, the objective of this article is to analyze the components of the innovation ecosystem and the ways of organizing innovative activities, to suggest their classification comprising internal and external types of organization with regard to railway transport.

Methods. The study is based on a comparative analysis of the practices of the most competitive railway companies.

\section{Results. \\ Innovative development and digitalization in the Russian Federation}

The tasks of innovative development under the conditions of the fourth industrial revolution and the digitalization paradigm are relevant for most countries of the world.

In the Russian Federation, measures aimed at increasing the digitalization of the economy and social sphere are carried out in accordance with the Decree of the President of the Russian Federation dated May 07, 2018 No. 204 «On national goals and strategic tasks of development of the Russian Federation for the period until 2024». To achieve these goals, national projects (programs) were developed, including the national program «Digital economy of the Russian Federation» (hereinafter - the National Program). The objectives of the National Program are aimed at comprehensive digitalization of priority sectors of the economy and social sphere of the Russian Federation [4]. The implementation of breakthrough scientific, technological and socio-economic development is planned to be ensured, inter alia, through implementation of priority projects using «endto-end» digital technologies, which include: big data, quantum technologies, components of robotics and sensorics, neurotechnologies and artificial intelligence, new manufacturing technologies, industrial Internet, distributed registry systems, wireless technologies, virtual and augmented reality technologies. Fulfillment of the tasks of breakthrough development and mass digitalization, including through implementation of projects based on the use of «end-to-end» digital technologies, also implies the need to modernize the innovation ecosystem at both the macro and micro levels.

The passport of the National Program includes a number of activities aimed at improving the innovation ecosystem of leading domestic state-owned corporations and companies with state participation, especially regarding development of the digital agenda, including:

- development and approval of digital transformation strategies;

- appointment of deputy officials in state corporations and companies with state participation, implementing digital transformation strategies, empowered and provided with resources for implementation of relevant initiatives and projects that is the appointment of Chief Digital Officers;

- development of an integrated project financing system based on the use of «end-toend» digital technologies and platform solutions with active participation of state corporations and companies with state participation.

One of the sections of digital transformation strategies is devoted to development of innovation management system and innovation infrastructure, interaction of companies with third-party organizations.

The criticality of development of this direction with respect to railway transport is confirmed by the priority of scientific and technological development of the Russian Federation in terms of «The connectedness of the territory of the Russian Federation through creation of intelligent transport and telecommunication systems, as well as the attaining and keeping leadership positions in creation of international transport and logistics systems, development and use of space and airspace, the oceans, the Arctic and the Antarctic» [5].

The potential and criticality of railway sector as one of the drivers of scientific and technological development in the Russian Federation are confirmed historically: during their early 
Innovation ecosystem of the railway industry

Identification of priority vectors of scientifictechnical development

Coordination of common efforts, promotion of cooperation

Stimulating participants for innovative development, $R \& D$

Organization and implementation of joint projects, $R \& D$

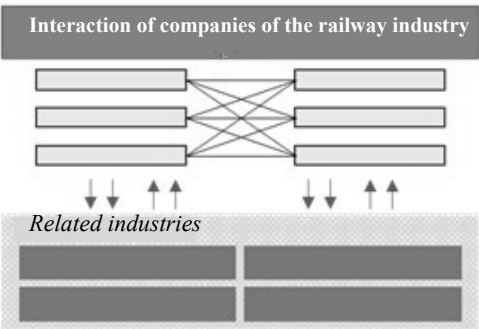

Pic. 1. The place and role of international associations in the innovation ecosystem of the railway industry.

developments mobile communications in Russia were initially introduced and then modernized on the railways. On May 30, 2019, JSC Russian Railways was selected as a leader in developments in the field related to development of quantum communications [6].

World practices of organizing innovation activity and innovation ecosystems: international associations

There are many examples of world best practices in organizing innovation activity and restructuring an innovation ecosystem $[7,8]$.

With regard to the activities of railways, international associations, occupying an important position in the innovation ecosystem, are becoming increasingly influential (see Pic. 1).

The significant role of such organizations, analogous to network international alliances, is explained through several key aspects (which include, but are not limited to, the listed):

- combining key competencies, skills, resources, technologies and experience of various participants in order to obtain synergy;

- discussion on critical issues, problems and initiatives affecting the interests of a wide range of stakeholders, including commercial companies and state authorities;

- identification of priority vectors for longterm development of the industry, including areas of scientific and technological development, and interaction with related sectors of the economy [9].

International associations act as visionaries, forming a long-distance vision for development of the industry for most of its key participants, including railway operators, owners of infrastructure facilities, manufacturers of railway and auxiliary machinery and equipment. With access to international interdisciplinary expertise, international associations are both qualified customers and responsible actors of global research dedicated to identify future trends.

Among the most characteristic examples are:

- foresight study of the International Union of Railways (hereinafter referred to as UIC) «A Global Vision for Railway Development»;

- foresight study ERRAC «Rail 2050 Vision».

The UIC foresight study «A Global Vision for Railway Development» contains a long-term vision of development of the railway industry, and also identifies a number of key driving forces necessary for its speedy achievement [10], including:

- coordinated knowledge management, taking into account technical requirements for research and development results, as well as potential risks, costs and opportunities;

- providing open access to industry expertise;

- active international cooperation through formation of sustainable partnerships with participation of small and research sectors;

- development of intersectoral cooperation.

According to the statement of the former UIC Director General, Jean-Pierre Loubinoux, the UIC is interested in facilitating cooperation among its participants from various regions and in joint search for answers to key challenges of the railway industry. In particular, for such purposes, the international railway research board (IRRB) has been created under the auspices of the UIC, being a platform for interaction and exchange of research and innovation results in the field of railway transport.

In order to develop international cooperation, support and coordinate research and innovation in the field of railway development, Shift2Rail initiative was put forward in 2014, which is the first European initiative in the railway industry

WORLD OF TRANSPORT AND TRANSPORTATION, Vol. 17, Iss. 4, pp.244-258 (2019) 
Innovation programs of Shift2Rail

\begin{tabular}{|c|c|c|c|c|c|}
\hline Structural and functional subsystems & IP 1 & IP 2 & IP 3 & IP 4 & IP 5 \\
\hline Long term needs and socio-economic studies & \multirow{5}{*}{ 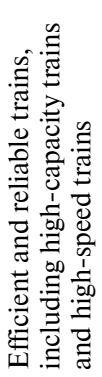 } & \multirow{5}{*}{ 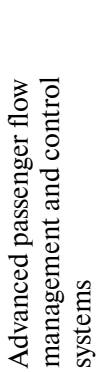 } & \multirow{5}{*}{ 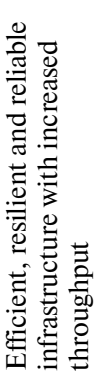 } & \multirow{5}{*}{ 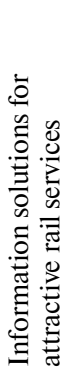 } & \multirow{5}{*}{ 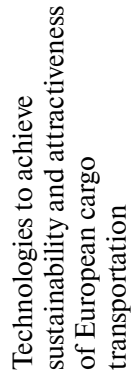 } \\
\hline Smart materials and processes & & & & & \\
\hline System integration, security, and compatibility & & & & & \\
\hline Energy and sustainability & & & & & \\
\hline Human capital & & & & & \\
\hline
\end{tabular}

aimed at research, innovation and market solutions.

Shift2Rail is a prime example of an institution (association) that brings together stakeholders and accelerates development and innovation in the railway industry. This initiative was established for a period up to 2024 with a total funding of more than Euro 900 million.

Research activities of Shift2Rail are concentrated in the framework of 5 priority areas - innovative programs (hereinafter referred to as IP) [11], covering all key structural and functional subsystems of the railway industry (Table 1).

The implementation of the presented 5 IP implies the use of both budgetary and extrabudgetary sources of financing, including own funds of the companies involved in Shift2Rail. One of the key responsibilities of the participants in this European initiative is independent conduct of research and development in areas similar to IP. Thus, Shift2Rail has a direct impact on the innovation system and development of the railway industry as a whole.

As emphasized above, international associations play a significant role in the innovation ecosystem of the railway industry, acting as visionaries and coordinators of innovative activities implemented by key industry stakeholders.

\section{Organization of innovation activity: practices of leading railway companies}

Railway companiesare often multidisciplinary holding structures whose main activities refer to various areas: cargo transportation, passenger transportation, maintenance of infrastructure facilities, provision of locomotive traction, etc. Such specifics determine wide presence within the organizational structure of companies of developed scientific and technical entities that include clusters in research centers, institutes and laboratories, as well as clusters with participation of specialized affiliated and partner universities.

The area of responsibility of these institutions in the field of organization of innovation policy of railway companies includes (including, but not limited to):

- training and retraining of highly qualified personnel in accordance with priorities and objectives of scientific, technological and innovative development;

- conducting analytical and strategic studies in order to identify narrow areas and development priorities of the company in the short, medium and long-term time period;

- organization and implementation of research and development in accordance with the system of end-to-end scientific, technological and strategic priorities;

- implementation of external and internal (between structural divisions, subsidiaries and dependent companies, branches of the parent company) technological transfer;

- interaction with participants in the external innovation environment in order to increase the level of competitiveness and to enhance research and technological development.

The organization methods described above are components of the innovation ecosystem of railway companies. These methods of organization are also conditionally divided into two types:

- internal type of organization of innovative activity is characterized by the presence of a structural unit that is comprehensively engaged in research and development; by independent 
Practices of organizing innovative activities by leading foreign railway companies

\begin{tabular}{|c|c|c|c|c|c|c|c|c|c|c|c|}
\hline & 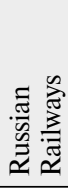 & 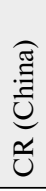 & 胥 & 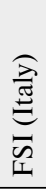 & 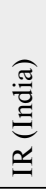 & 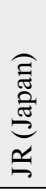 & 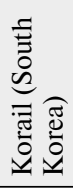 & 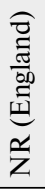 & 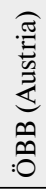 & 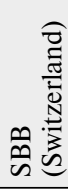 & 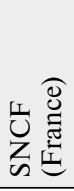 \\
\hline Innovation $(\mathrm{R} \& \mathrm{D})$ center & $\checkmark$ & $\checkmark$ & $\checkmark$ & $\checkmark$ & $\checkmark$ & $\checkmark$ & $\checkmark$ & $\checkmark$ & $\checkmark$ & $\checkmark$ & $\checkmark$ \\
\hline Business accelerator & - & $*$ & $\checkmark$ & - & $*$ & $\checkmark$ & * & $*$ & $\checkmark$ & $*$ & $\checkmark$ \\
\hline Startup business incubator & - & $*$ & $\checkmark$ & $\checkmark$ & $\checkmark$ & $*$ & $*$ & $*$ & $*$ & $*$ & $\checkmark$ \\
\hline Corporate venture fund & - & - & $\checkmark$ & $*$ & $*$ & - & $*$ & - & $*$ & $\checkmark$ & $\checkmark$ \\
\hline Hackathons & - & - & $\checkmark$ & $\checkmark$ & $*$ & $\checkmark$ & - & $\checkmark$ & $\checkmark$ & $\checkmark$ & $\checkmark$ \\
\hline
\end{tabular}

« $\checkmark-$ the corresponding instrument is used in the company;

$\langle * »-$ there are indirect signs of using the corresponding instrument in the company;

«-» - the corresponding instrument is not used in the company.

development and commercialization of innovative solutions; by lack of interaction with external organizations;

- external type of organization of innovative activity is distinguished by the absence of a structural unit within corporate HQ that is exclusively responsible for research and development; by acquisition of ready-made solutions and services; by wide-range partnerships; by interaction with technology centers, incubators and startups.

In the context of mass digitalization of all sectors of the economy and social sphere, when the technological and innovation cycles are significantly reduced in terms of implementation time, one of the global trends is intensification of cooperation between companies and the actors belonging to the external innovation environment following the principle of «open innovation», including representatives of small and mediumsized enterprises (hereinafter - SME). This principle implies cooperation with third parties (for example, universities, competitors or customers), which opens up access to complementary knowledge, markets and networks [12].

Practices of leading foreign railway companies (see Table 2) in the field of organizing research and development show that the following tools were most widely used:

1) organization of independent innovation laboratories and / or research and development centers;

2) organization and conduct of innovationoriented activities, including hackathons;

3) interaction with startups and SME, within the framework of functioning of:

- corporate or partner business accelerators and business incubators;
- corporate and multi-corporate venture funds.

Carrying out innovation-oriented events, interaction with external partners, including startups, business incubators and business accelerators, provides access to advanced developments and technologies that lie outside the company's internal control and industry specifics [12].

Table 2 shows the distribution of selected research and development organization tools within leading foreign railway companies. As part of the analysis, we studied companies with a business model similar to the JSC Russian Railways.

It is worth noting that JSC Russian Railways is developing many forms of support of innovative activities that are not typical of other companies' corporate practices, e.g. regarding the students of transport universities, development of close and efficient interaction with Russian academy of sciences. Single innovation «window» (office) of Russian Railways is another eloquent example of the initiative in the field of support of intercorporate and extra corporate innovative activities. This initiative is implemented through dedicated Website that enables reception of innovative proposals and offers and their processing by corporate experts. Suggestions can be sent by individuals as well as by legal entities with different legal status*.

The main activities of the reviewed companies are:

- passenger and cargo railway transportation;

- provision of logistics services;

- provision of access to railway infrastructure facilities.

* [Electronic resource]: https:// innovation .rzd .ru/ front/.

- WORLD OF TRANSPORT AND TRANSPORTATION, Vol. 17, Iss. 4, pp.244-258 (2019) 
All railway companies presented in Table 2 are actively implementing measures aimed at developing critical thinking of employees, principles of project management (including the principles of lean production) and knowledge management systems. These initiatives contribute, inter alia, to development of internal business: implementation of innovative projects by company employees independently from their main employment [13].

For competent management of innovations, it is necessary to develop employees' awareness about the importance of innovation and professional competencies of all the stakeholders [14].

The greatest innovative activity and the use of a wide range of different tools can be highlighted regarding the following companies:

- Deutsche Bahn (DB): Germany;

- SNCF: France;

- JR Group (JR): Japan;

- SBB-CFF-FFS (SBB): Switzerland;

- FS Italiane (FSI): Italy.

An important feature of leading railway companies is that they implement a mixed type of organization of innovative activity. There are also companies that have no internal units responsible for management, coordination and implementation of research and development, for example: Amtrak (USA), NSB (Norway).

In turn, all the railway companies listed in Table 2 actively apply the strategy of building mutually beneficial long-term partnerships and joint ventures, including organization of joint research and development centers: for example, in China it is a joint innovation center of China Railway and Huawei telecommunications company.

SNCF is a party to mutually beneficial partnerships with more than 30 industrial companies, research institutes and international laboratories in various sectors of the economy. Under these agreements, SNCF adheres to the concept of open innovation, contributing to overall development of the railway industry.

The railway company SBB-CFF-FFS is an integrator of various innovative solutions in Switzerland and pays significant attention to development of the practices of signing mutually beneficial and long-term partnership agreements with research institutes and universities.

Conclusions. Analyzing advantages and disadvantages of the external and mixed types of organization of innovative activity, it should be noted that railway companies using tools of both external and internal types are characterized by a high level of competitiveness and technological development.

The external type of organization of innovation activity has a positive effect on reducing the costs required to organize and maintain its own infrastructure and departments responsible for conducting research and development, and also contributes to a better understanding of technological and market trends thanks to active interaction with external organizations and companies. However, adhering to an exclusively external type in implementation of innovative activities, makes those railway companies largely dependent on outside organizations regarding most aspects of their activities.

The implementation of solutions that correspond to the internal type of organization of innovation activity, that is, implementation of research and development within their own innovation laboratories and $R \& D$ centers, allows railway companies to significantly reduce this dependence. The disadvantage of the internal type is high level of costs required for research and development, training of highly qualified personnel, as well as providing them with necessary equipment and resources. Conducting exclusively own research and development is associated with the risk of obtaining results that do not correspond to the best world standards.

The optimal and effective way of organizing the innovation activity of a railway company passes, in our opinion, through implementation of a mixed type, which includes both elements of independent research and development, and active interaction with external organizations, companies and specialists. This is confirmed by the fact that most of the analyzed companies adhere to this type of organization of innovative activity, independently carrying out research and development within their own R\&D centers and/or innovative laboratories, as well as actively cooperating with other companies and startups.

The identification of areas of technological development, within the framework of which it is possible and expedient to conduct independent research and development in order to obtain results corresponding to a high level of competitiveness, is carried out by leading foreign railway companies in accordance with current knowledge, competencies and technologies that they possess and which are necessary to achieve such results. The exploration of technological 
development areas in which a railway company does not have sufficient experience and knowledge is carried out within the framework of the external type of organization of innovation activity, in particular, within the framework of the policy of net consumption of technological and product solutions in the form of ready-made technologies (services).

In the future, subject to further training of employees of a company and its subsidiaries and acquisition of relevant knowledge and competencies, development of such technology, including next-generation solutions, can be carried out by such a company independently or as part of a consortium.

\section{REFERENCES}

1. Sadovnichy, V. A., Akaev, A. A., Korotaev, A. V., Malkov, S. Yu. Modeling and forecasting of world dynamics [Modelirovanie i prognozirovanie mirovoi dinamiki]. Scientific council on the fundamental research program of the Presidium of the Russian Academy of Sciences «Economics and Sociology of Knowledge». Moscow, ISPI RAS publ., 2012, 359 p.

2. Alyabyev, S. [et al]. Innovation in Russia is an inexhaustible source of growth [Innovatsii v Rossii neischerpaemiy istochnik rosta]. McKinsey Innovation Practice Center for Innovation Development, 2018, 112 p.

3. Zheleznov, M. M. On the concept of information and technological improvement of the track management system based on innovative technologies, including satellite $[O$ kontseptsii informatsionno-tekhnologicheskogo sovershenstvovaniya sistemy vedeniya putevogo khozyaistva na osnove innovatsionnykh tekhnologii, v tom chisel sputnikovykh]. Bulletin of the Joint Scientific Council of JSC Russian Railways, 2012, Iss. 5, pp. 1-7.

4. Passport of the National Program «Digital economy of the Russian Federation» (approved by the Presidium of the Council under the President of the Russian Federation for strategic development and national projects, Minutes dated December 24, 2018 No. 16) [Pasport Natsionalnoi programmy «Tsifrovaya ekonomika Rossiiskoi Federatsii» (utverzhden prezidiumom Soveta pri Prezidente Rossiiskoi Federatsii po strategicheskomu razvitiyu i natsionalnym proektam, protocol ot 24 dekabrya 2018 g. No. 16)]

5 . The strategy of scientific and technological development of the Russian Federation (approved by Decree of the President of the Russian Federation of December 1, 2016 No. 642) [Strategiva nauchno-tekhnologicheskogo razvitiya Rossiiskoi Federatsii (utverzhdena Ukazom Prezidenta Rossiiskoi Federatsii ot 1 dekabrya 2016g. No 642)].

6. Meeting on development of technologies in the field of artificial intelligence [Soveshchanie po voprosam razvitiya tekhnologiiv voblasti iskustvennogo intellekta]. President of Russia: official website. [Electronic resource]: http://kremlin.ru/ events/president/news/60630. Last accessed 25.06.2019.

7. Zheleznov, M. M. The concept of monitoring and maintaining the infrastructure of the railway transport corridors of CIS countries « 1520 space» based on satellite and geographic information technologies [Kontseptsiya monitoringa i soderzhaniya infrastruktury transportnykh zheleznoorozhnykh koridorov stran SNG «Prostranstvo 1520» na osnove sputnikovykh igeoinformatsionnykh tekhnologii]. Bulletin of the Joint Scientific Council of JSC Russian Railways, 2011, Iss. 2, pp. 34-37.

8. Rosenberg, I. N., Zheleznov, M. M. Prospects for development of technologies for monitoring and maintaining the infrastructure of the CIS railway transport corridors «Space $1520 »$ based on satellite and geoinformation technologies [Perspektivy razvitiya tekhnologii monitoringa i soderzhaniya infrastruktury transportnykh zheleznodorozhnykh koridorov stran SNG «Prostranstvo 1520» na osnove sputnikovykh igeoinformatsionnykh tekhnologii]. Vestnik transporta Povolzhiya, 2012, Iss. 6, pp. 36-39.

9. Zheleznov, M. M. On the priority areas of scientific research of JSC VNIIZhT [O priotetnykh napravleniyakh nauchnykh issledovanii OAO VNIIZhT]. Bulletin of the Joint Scientific Council of JSC Russian Railways, 2013, Iss. 6, pp. 28-33.

10. Global vision for Railway Development. Foresight Study of the International Board for Railway Research [Globalnoe videnie razvitiya zheleznodorozhnogo transporta. Forsait-issledovanie Mezhdunarodnogo soveta po zheleznodorozhnym issledovaniyam]. UIC Communication Department, 2015, $44 \mathrm{p}$.

11. Research and development program [Programma issledovanii i razrabotok]. Shift2Rail: official website. [Electronic resource]: https://shift2rail.org/research-development/. Last accessed 27.06.2019.

12. Grossfeld, T., Rolandt, T. D. A. The logic of open innovation: creating value by combining networks and knowledge [Logika otkrytykh innovatsii:sozdanie stoimostiputem ob'edineniya setei i znanii]. Foresight, 2008, Vol. 2, Iss. 1, pp. 24-29. [Electronic resource]: https://elibrary.ru/item. asp?id=16390108/ Last accessed 29.08.2019.

13. Zheleznov, M. M. The main stages of development of scientific knowledge and high technology in the track facilities'complex. Innovative transfer to the infrastructure of railway transport [Osnovnie etapy razvitiya nauchnogo znaniya $i$ vysokikh tekhnologii v putevom komplekse. Innovatsionniy transfert $v$ infrastrukturu zheleznodorozhnogo transporta]. Basic research for long-term development of railway transport: collection of works of members and scientific partners of the Joint Scientific Council of JSC Russian Railways. Ed. by B. M. Lapidus. Moscow, Intext publ., 2013, pp. 176-184.

14. Fedyukovich, E. V. Corporate entrepreneurship: economic and organizational aspects [Korporativnoe predprinimatelstvo: ekonomicheskie i organizatsionnie aspekty]. Rossiiskoe predprinimatelstvo, 2016, Vol. 17, Iss. 8, pp. 951-966.

15. Terekhova, T. A. Competence approach to management of innovative changes [Kompetentnostniy podkhod $v$ upravenii innovatsionnymi izmeneniyami]. Psikhologiya v ekonomike i upravlenii, 2010, Iss. 1, pp. 31-37.

\footnotetext{
The authors are grateful to the colleagues who took part in the research, the results of which were used to prepare the paper: Trostyansky Sergey S., Master in Economics, deputy director of the Center for storage and analysis of big data, Lomonosov Moscow State University; Rakov Dmitry A., Master in Management, leading specialist of the Center for storage and analysis of big data, Lomonosov Moscow State University; Smirnov Roman G., Master in Economics, leading specialist of the Center for storage and analysis of big data, Lomonosov Moscow State University; Smirnova Tatyana V., Ph.D. student at the department of statistics, leading economist at the faculty of economics of Lomonosov Moscow State University; Tereshchenko Igor A., Master in Law, leading specialist of the Center for storage and analysis of big data of Lomonosov Moscow State University; Titova Yulia A., Master in Management, leading specialist of the Center for storage and analysis of big data of Lomonosov Moscow State University.
}

WORLD OF TRANSPORT AND TRANSPORTATION, Vol. 17, Iss. 4, pp. 244-258 (2019) 